\title{
Role of the Cognitive Research Trust Thinking Program in Developing Critical Thinking Skills*
}

\section{Sevda DOĞAN DOLAPÇIOĞLU*}

\section{Ahmet DoĞANAY***}

\begin{abstract}
This study focuses on the role of Cognitive Research Trust (CoRT) thinking program in developing critical thinking skills and aims to contribute to the curriculums for all school levels in Turkey for teaching critical thinking skills adopting a qualitative case study design. For this purpose, 35 grade 5 students from a primary school and their teacher participated in the study. The data were collected through student reflections and teacher views following each thinking education course for ten weeks. Ten lessons included in the fifth section of the CoRT program, "knowledge and feelings", which was considered to be related to critical thinking skills were taught for ten weeks as one lesson, four activities, and one project per week. Findings revealed that the CoRT program achieves important outcomes in critical thinking regarding opinions, which may be directed by feelings, values, and others' ideas. Findings also indicated that information may not always be accurate; therefore, it should be investigated, clarified, and simplified It can also be acquired through clues and questioning. In addition, findings suggested that for making the CoRT program more effective, classes should include visuals and real-life examples.
\end{abstract}

Keywords: Critical thinking, CoRT, knowledge and feelings.

\footnotetext{
${ }^{*}$ Part of this paper was presented at the 2nd National Congress on Curriculum and Instruction, October 2012, in Bolu, Turkey.

Ethics committee approval for this study was obtained from Hatay Mustafa Kemal University Scientific Research and Publication Ethics Committee, dated 23/06/2021 and protocol number 10.

${ }^{* *}$ Orcid ID: https://orcid.org/0000-0002-2707-1744, Assoc. Prof. Dr., Hatay Mustafa Kemal University, Turkey, sdolapcioglu@mku.edu.tr

*** Orcid ID: https://orcid.org/0000-0002-8482-225X, Prof. Dr., Çukurova University, Turkey, adoganay@cu.edu.tr Doğan Dolapçığlu, S. \& Doğanay, A. (2021). Role of the Cognitive Research Trust Thinking Program in Developing Critical Thinking Skills. Sakarya University Journal of Education, 11(2), 396-411. doi: https://doi.org/10.19126/suje.743683
} 


\section{INTRODUCTION}

The development of critical thinking skills in students is essential and its importance has accordingly been often emphasized in literature and national curricula. Saban (2004) indicated that the development of critical thinking skills has important implications for the individuals as it facilitates questioning of information. Students with critical thinking skills differ from those who never acquired these skills in terms of combining information as well as their ways of self-view and evaluation (Akınoğlu, 2001). Critical thinking actively nurtures students (Browne \& Freeman, 2000) as well as helps individuals identify, distinguish, and evaluate their detailed characteristics (Enright \& Beatie, 1992). Critical thinking skills are necessary in the 21st century and should be developed (Preus, 2012). That is because of the fact that questioning accuracy of information is crucial today since there is too much information pollution, and critical thinking aids this. Critical thinking and other high-level thinking skills can be gained through education at every age and level of learning (De Bono, 1991). In the era of information pollution and rapid changes, there has not yet been a satisfactory conclusion about the acquisition of these skills by students although teaching critical thinking skills is well accepted in studies of curriculum development and teaching. The primary reason for this is the lack of clarity concerning what constitutes high-level thinking skills and its implementation in schools. In general, to acquire critical thinking skills, high-level thinking skills in teaching programs is considered a priority (Safran et al., 2005); however, the activities needed for teaching them are not clarified (Barak \& Doppelt, 1999). They can be improved only by detailed practice as these are identifiable, distinguishable, and evaluable (Enright \& Beatie, 1992). In response to this need, the study presents an evaluation of a course, with clear guidelines and activities for teaching critical thinking skills. Moreover, it indicates the benefits of the program in terms of developing critical thinking skills.

\section{Teaching Critical Thinking Skills}

Critical thinking, which is derived from the Greek term critik, is defined as the art of critiquing and judging. Socrates, the founder of critical thinking, described it as an inquiry method (Ruppel, 2011). Ennis (1991) listed critical thinking skills and attitudes as searching for reasons, evaluating the adequacy of evidence and reasons, supporting, clarifying, and inferring. Browne and Freeman (2000) stated that critical thinking is multidirectional and actively supports students. It is possible to plan a course that aims at teaching critical thinking skills in several different ways. One of the ways to teach these skills is to offer them as a separate unit or lesson in a skill-based manner. Another way is to integrate them with the available content or to present both together (Aybek, 2007; Beyer, 1991; Doganay, 1999; Paul \& Elder, 2007). In addition, as Şenşekerci and Bilgin (2008) stated, critical thinking skills can be promoted through some methods such as six thinking hats, brainstorming, questioning method, intellectual norms activity, and critical media literacy education method. However, regardless of the method selected, it is important to consider the teaching of critical skills as information transfer, problems in planning the duration, and the loneliness of the teacher (Onosko, 1991). 
That is why Browne and Freeman (2000) heavily focused on the behavioral traits of students who think critically. They emphasized that critical thinking classes display wide characteristics for a range of frequently asked questions, supporting change, and encouraging active learning. Similarly, Harold (1938) stated that students should be aware of providing evidence to support the use of critical thinking skills while participating in the lesson, recognizing spoken and unspoken assumptions that are important to the outcome, rejecting and accepting those assumptions by evaluating them, and reviewing the assumptions underlying their own beliefs (as cited in Marcut, 2005). According to Özdemir (2005), besides the family, the school and the teacher in particular play an important role in the development of individuals' thinking skills because critical thinking develops depending on the student's use of the information provided by the teacher effectively (Seferoğlu \& Akbıyı, 2006; Güven \& Kürüm, 2006) and basically includes skills that require questioning (Kurt \& Kürüm, 2010).

\section{The Cognitive Research Trust Program}

The Cognitive Research Trust (CoRT) program has been used in research fields related to thinking for many years and aims to develop thinking skills in students. Studies have indicated that the CoRT program supports critical thinking, creative thinking, communication skills, and problem-solving skills (Alshurman, 2017; Bayrak \& Aktaş, 2016; Daher, Tabaja, Gidan, \& Gierdien, 2017; Doganay \& Dolapçığlu, 2012; Ngang et al., 2014). Bono (1986), for example suggested that the CoRT program teaches thinking skills by directly increasing the variety of ideas through individual goal setting, prioritization, social communication, and incorporation of emotions into thinking. In addition, the fifth lesson of the CoRT program, "knowledge and feelings," emphasizes critical thinking skills. The first lesson focuses on information given and missed; second lesson indicates the difference between asking questions for information and asking them for approval; fourth lesson includes activities related to the examination of clues separately and together, questioning of information, and exploration of contradictions; fifth lesson is based on estimations and their foundations; sixth lesson concerns the questioning of beliefs; seventh lesson is related to questioning the opinions of others or accepting them as they are; eight lesson includes activities about feelings and ego; ninth lesson focuses on value education; and finally, the tenth lesson focuses on clarification and simplification.

Educating students for higher-order thinking can help transform them into more critical thinkers. Those with critical thinking skills can become important people for the society and can overcome the problems in their lives. One way to do this is to promote educational programs that teach high-level thinking. This study discusses the use of such course tools and the problems encountered. In the study, answer for the following research question was investigated:

- At which components does the CoRT program, promoting critical thinking skills, support students? How? 


\section{METHOD}

\section{Research Model}

In accordance with the purpose of the study, we used a case study model to evaluate the benefits of the CoRT program. Case study is an empirical research method that investigates a contemporary phenomenon in its real-life context especially when the boundaries between the context and the phenomenon are not clearly evident; it is an indepth investigation and description of a bounded system (Yin, 2009; Merriam, 2013). This study explored and described the contributions of the CoRT Program to critical thinking skills.

\section{Participants and Setting}

Ethics committee approval for this study was obtained from Hatay Mustafa Kemal University Scientific Research and Publication Ethics Committee, dated 23/06/2021 and protocol number 10 . The study group comprised 35 middle school students and their teacher. The students (16 girls and 19 boys) were studying in Grade 5 at a public school in Turkey and were with middle socio-economic status. The teacher was a 40-year-old male. He had been working as a primary school teacher for 20 years. Care was taken to ensure that the class was selected from a school located in a medium socioeconomic environment. This is because the aim was to study a phenomenon considering a situation that reflects the medium characteristics while sampling in a typical case study (Yıldırım \& Şimsek, 2016). The participants were employed through criterion sampling, one of the types of purposeful sampling. CoRT is a curriculum consisting of activities that foster critical thinking. In this study, the researcher followed development process by studying the activities included in this curriculum with the students.

\section{Data Collection Tool}

Reflections papers and journals, which are among reflective thinking methods, were used as data collection tools.

a) Reflection Papers: These are the articles in which students reflect their views on what they learned during the lesson. In accordance with the purpose of the study, the teacher and students were asked to express their relevant opinions in their reflections. These texts, reflecting students' reactions to learning, allowed them to express what they had learned and associated their learning with practice (Tang, 2000). Stoddart (2002) revealed that reflective journals facilitate the reflection of both experience and knowledge. In addition, student views were evaluated separately for each course, and the concepts were coded.

b) Interviews and journals: Further, face-to-face interviews with the teacher were analyzed individually and the concepts were coded. In the interview form; "What are your views on the contribution of the course to the students?" was expressed. In addition, the teacher kept a diary about the contribution of the course to the students. 


\section{Data Analysis}

The journals, the main data source of the study, were analyzed through content analysis. In this context, reflective journals were read several times and notes were taken with appropriate coding. In addition, face-to-face interviews with the teacher were transcribed and analyzed with teacher reflections. The reliability of coding, which was made by two scholars working in the field of curriculum development and instruction, was .86. The similarity of opinions between students and the teacher in their reflections was also considered important in terms of the reliability of the study. Similar opinions were presented together. Student opinions were coded as S6 (student 6). The courses were coded as CoRT 5/10 (the fifth of 10 CoRT courses).

\section{RESULTS}

The findings were modelled in Figure 1 as a concept map with the main theme of "information".

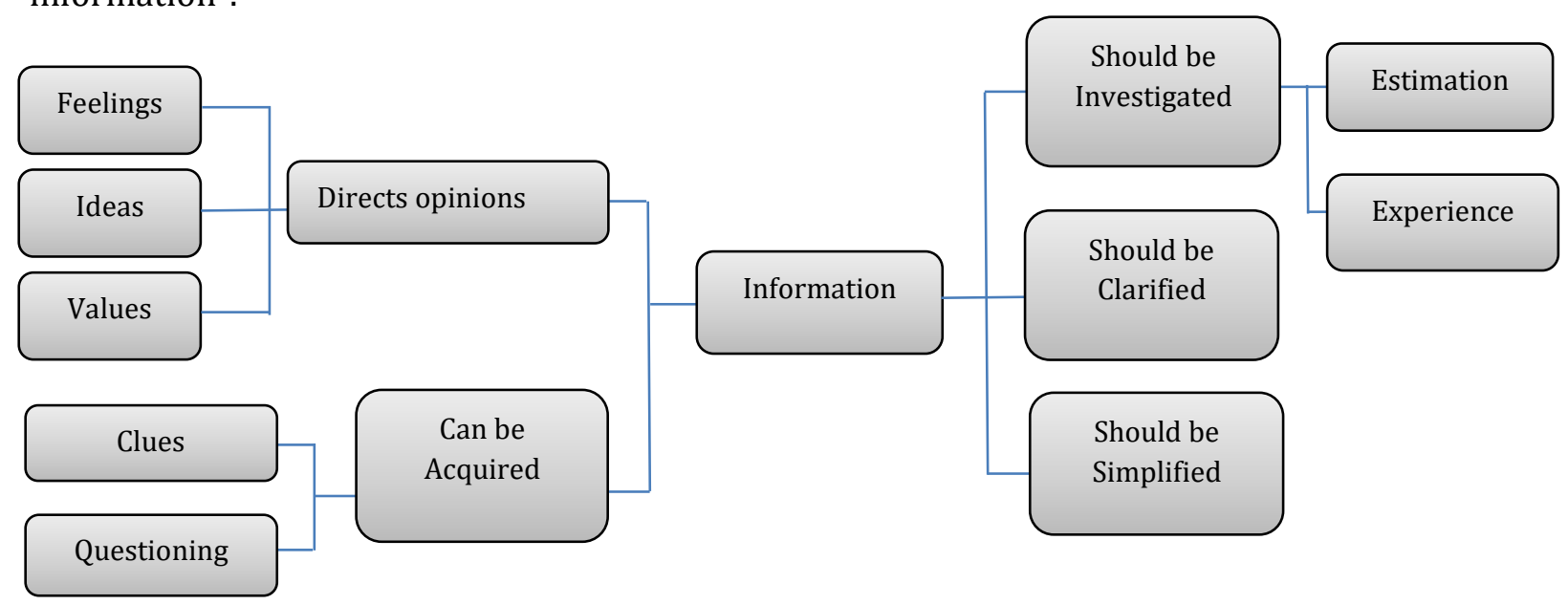

Figure 1. Findings Concerning the Development of Critical Thinking Skills

Figure 1 presents the themes and subthemes derived as a result of the content analysis of the teachers and students' reflective journals. The themes include the following: "opinions are directed," "information may not be accurate," and "information can be acquired under the category of critical thinking skills." The theme "opinions are shaped" comprises the subthemes as: "they are shaped by emotions," "they are shaped by values," and "they are shaped by others' opinions." The theme "information may not be accurate" comprises the subthemes as: "it may be imperfect or inaccurate," "it must be investigated (estimations and experiences)," "it must be clarified," and "it must be 
simplified." The theme "information can be acquired" comprises two subthemes as: "hinting" and "questioning."

\section{Opinions Are Shaped}

While students were learning critical thinking skills, they expressed that thoughts were influenced by emotions or by their own ideas and values. Students assessed that while they were working on the activity, others did not have to think like they did because all had different emotions. The teacher stated that during the lesson, students realized that each had different emotions. They might be influenced by different ideas, and these skills improve their interpretation skills.

\section{Ideas Shape Opinions}

The students particularly noticed that information was influenced by their own or others' ideas. In reflection letters, they wrote the following examples about how students' opinions were influenced by ideas:

"We get ready information, we pass some of it through our mind filters and add something from our own ideas" (S32) and "We add something from ourselves to some ideas, sometimes we take advantage of others' ideas" (S11).

\section{Emotions Shape Opinions}

Students were aware regarding people's feelings influencing opinions. The teacher expressed his considerations regarding this progress as follows:

"Students realized that different feelings affected opinions, so they comprehended and were very concerned that others did not have to think like they did or that they might not be the same as others" ( CoRT 5/8).

Student reflections on the same topic were in parallel with the opinions of the teacher:

"The opinions of a person at a time change from person to person because the current situation gives way to those opinions. Everyone is different from each other because they do not have the same feelings" (S1).

"There can be no feeling without opinions and no opinion without feeling; human opinions are influenced by the feeling at that moment." Students were given the opportunity to practice during the twelve activities in these three separate lessons, which emphasize questioning skills" (S24).

\section{Values Shape Opinions}

The teacher restated that the ninth course that emphasized the importance of values in the formation of opinions was very effective for the students. He argued that "it was perhaps the most exciting exercise for the students" and that "Students have explanations and examples of how opinions can be influenced by values and can vary from one person to another" (CoRT $5 \backslash 9$ ). In a similar vein, some participants stated the followings: 
"All our opinions are based on our judgments, actions, and the values we hold" (S18)

"The values people have are the ones that direct them. These values may sometimes be low or high" (S4)

"Our decisions differ according to the values we have, everybody has different values." (S3)

\section{Information May Not Always Be Accurate}

As students learned critical thinking skills, they stated that information may not always be accurate. Students particularly realized that estimations and experiences should be investigated; imperfect and inaccurate parts should be clarified; and information should be simplified. The teacher perceived that the skills would improve questioning and estimating skills.

\section{Information Should Be Investigated}

The teacher and students expressed in their reflections that it was useful to investigate the accuracy of information for questioning as follows:

"Students expressed verbally or in writing that not all information presented to them is correct and that the information and the results may conflict. It was a session that improved students' critical thinking skills, such as making judgments, making comparisons, drawing conclusions" CoRT 5/4. Some participants stated the followings:

"Some students stated that "every information given may not be correct, so we should always examine the information given to us and distinguish between accurate and inaccurate" (S33),

"in this study, I understood what conflicting information meant and that it could mislead us" (S7).

Regarding the capacity of the course in improving estimating skills, the teacher stated that "there was no difficulty in practice, students understood by practicing that they could make estimations in every subject, and it was imperative to research and acquire knowledge for this"( CoRT 5/5). Some participants stated the followings:

"About the same issue, the students reflected that "estimations may lead us to the wrong place, so we should research before making an estimation" (S5).

“.....estimations are not always correct, sometimes more information is needed" (S9).

The reflection of the students concerning investigations to get the roots of values was as follows:

"We believe in the truth of some information with our own experience" (S8),

"We should not believe everything others say. If we want to know something, we must find it out ourselves rather than learning from others" (S23). 


\section{Information Must Be Clarified And Simplified}

In their reflections, the students emphasized that they obtained the ability to see imperfect and inaccurate information when the information presented to them was unclear. Relevant student opinions were as follows:

"When I wrote an article, I realized that I could skip some things and sometimes I did not listen to people fully "(S3).

"In this course, I learned that some of the information I thought I knew in-depth had imperfect parts" (S1).

"I learned what critical thinking was and there is a mistake every person can make" (S35).

" when I wrote an article, I realized that I could skip some things and sometimes I did not listen to people fully" (S5).

Regarding clarification and simplification skills, the teacher stated that "students expressed they will use clarification and simplification while studying and expressing their emotions and opinions. Some students stated as follows:

"it is necessary to sometimes clarify or simplify information" (S23).

"Information is not always simple or clear. It is necessary to sometimes clarify or simplify information" (S6).

\section{Information Can Be Acquired}

While learning critical thinking skills, students expressed that it was effective to question and combine clues to obtain information. The teacher perceived that these skills could improve questioning and estimating. In addition, the teacher stated that the students used questioning and clues in their lessons to obtain information.

"During the study, students realized that it was important to ask questions for obtaining information, and they could not obtain information without asking questions" (CoRT $5 / 2$ ).

Writing example questions by defining question types and the role of questioning in learning, the students mentioned the followings in their reflection papers:

"The best way of learning is to ask questions, people ask questions and obtain new information" (S5),

"During the course, I asked questions to investigate and check. I learned that it is useful to ask questions and that it has an important place in learning" (S32).

Emphasizing the value of the program in terms of usability in combining different hints and arriving at a conclusion, the teacher expressed his views as follows:

"They like to find very different and interesting clues. The program has been useful in teaching how to use various clues to reach a result" (CoRT 5/3.) 
The students had similar ideas in their reflections:

"I have learned that combining small information through clues leads to solving and finding all things," (S8)

"Small information, in other words clues are needed to reach a bigger information " (S23)

\section{Suggestions}

The teacher made suggestions such as having visuals in the lesson, choosing the samples from the students' social circles, and replicating the materials for the students. The teacher:

"I think this course will be more effective in practice if the number of visual cartoons is increased. Also, if the terms in the course are appropriate to the level, they can be more instructive" (CoRT 5\1).

In conclusion, it can be clearly stated that the CoRT thinking program offers benefits parallel to the program goals; therefore, it should be covered in the program by conducting development studies. The study attracted interest and was loved by the students. This program was beneficial for the students because the gains of the program were considered in skill dimension and were supported by activities.

During the analysis of data, there were three subthemes, i.e., duration, ongoing program content, and deficiencies in materials, under the category of "obstacles in course implementation." The teacher stated that he suffered from the classroom size, duration, material language, content anxiety, etc. In particular, he stated that these obstacles hindered student participation and that his anxiety in covering the content in the existing program created problems in implementation. For example, the teacher noted the difficulties he experienced in the implementation of CoRT program lessons as follows:

"This week's activities in the course could not be covered and delayed. The study provoked a lot of interest, but the size of the classroom and time constraints from other lessons prevented us from completing all the activities" (CoRT 5/1).

"I had the course within the program of free activities courses. In the course, many students stated that they want to participate, focus more on the issues, and be knowledgeable but that the time was not enough" (CoRT 5/2).

To make the course more practicable in terms of student participation and benefits, suggestions were received regarding the three subcategories of material, duration, and manner of implementation mentioned in reflective journals. The suggestions allowed the researchers to evaluate and improve the CoRT program during course implementation. For example, because the teacher reflected as follows;

"During the course implementation, the fact that only I possessed the materials caused the students to spend more time to comprehend the content and hence lose time" (CoRT: 5/2). 
It was also seen that thinking training could be refined by program development studies. Once these materials were available, the teacher reflected;

"I have had the opportunity to finish all the work for the first time because the students have the activities in front of them, thanks" (CoRT 5/3).

In addition, the teacher reported after many lessons that the subject of the activities related to the CoRT material was abstract to the students and that they were concerned about foreign names and examples in the activities. Regarding this, the teacher stated as follows;

"I believe that it will be better to adjust some topics and terms in the material covered according to students' age and level of knowledge."

\section{DISCUSSION, CONCLUSION AND SUGGESTIONS}

It was concluded that the CoRT program developed students' awareness of critical thinking for the components that opinions can be shaped by feelings, values, and others' ideas; information may not always be accurate; it should be investigated, clarified, and simplified; it can be acquired through clues and questioning. All these subthemes are crucial perceptions of development for critical thinking. The CoRT program has been used in fields related to thinking for many years and aims to develop thinking skills in students (Alshurman, 2017; Daher, Tabaja, Gidan, \& Gierdien, 2017; Bayrak \& Aktaş, 2016; Doganay \& Dolapçığlu, 2011; Karakuş, 2001; Ngang et al., 2014). Bono (1986) suggested that the CoRT program teaches thinking skills by directly increasing the variety of ideas through individual goal setting, prioritization, social communication, and incorporation of emotions into thinking. Likewise, the students and the teacher in this study argued that they could improve their ability to draw inferences in these courses through questioning and combining clues, expressing that information must be investigated, clarified, and simplified by knowing that information may not always be accurate. Critical thinking skills and attitudes comprise skills for searching reasons, evaluating the adequacy of evidence and reasons, supporting, clarifying, and inferring (Ennis, 1991). Accordingly, the skills that students gain can support their learning of critical thinking by increasing the diversity and number of ideas. If individuals with critical thinking skills are to be trained, there should be activities that offer students the opportunity to work on these skills in detail on real events, such as the CoRT program. Mentioning these skills only in the curriculum outcomes is inadequate because teachers and students need a good guide for practical purposes. The CoRT program, similar to other thinking programs, offers clear and comprehensible ways to improve the thinking processes and learning skills (Mc Gregor, 2007). Melchior, Kufold, and Edwards (1988) stated that the CoRT lessons taught students how to reflect on their own principles and evaluate other people's views. It especially helped them in analyzing literary characters, drawing up a development plan, and creating and organizing ideas for writing assignments. Moreover, the teaching of critical thinking based on real life situations 
without depending on a context may have supported the development of skills. This program, which offers opportunities for problem-solving to students in real life situations, supports critical thinking. This is because problem-based learning activities promote critical thinking (Iwako, Li, \& Rhee, 2010; Khalid, 2010).

Toptaş (2010) found that the teachers were "sometimes" successful with regard to the skills of problem-solving, communication, reasoning, and associating in primary school mathematics program. However, the teaching of these skills should be planned in more detail (De Bono, 1991; Enright \& Beatie, 1992; Demirkaya, 2008). Another finding of the study was that opinions may be influenced by feelings, values, and others' ideas and clues and questioning should be used in acquiring information. The CoRT course can also provide students the opportunity to acquire these skills by presenting detailed practice opportunities to find solutions, investigate, and generate ideas. White (2010) stated that critical thinking must be applied to something that has its own principles. Therefore, independent of the teaching of content matter, thinking activities should be offered to students by placing them at regular intervals within each curriculum. In this study, an activity is planned as a separate lesson each day. According to Doganay (2009), the prerequisite of critical thinking is to have preliminary knowledge about the subject. It is impossible to reason or judge a subject without any prior knowledge of it. With the help of the CoRT program, the learners have prior knowledge as it is based on familiar real-life content (Barak \& Doppelt, 1999). Therefore, integrating courses into the program is considered to provide support only for the teaching of critical thinking skills without introducing a new content burden. The greatest shortcoming in terms of thinking skills in curricula is that instruction remains in the shadow of content teaching. De Bono (1991) explained this situation with the example of losing the forest while looking at the trees and stated that the development of thinking skills should be based on familiar real-life issues and practice. Similarly, Lan (2002) noted that the development of these skills must be supported by offering a separate lesson, such as teaching critical thinking, or supporting the development of critical thinking skills in teaching other disciplines by including activities that can promote critical thinking skills. The education system must be urgently evaluated within the framework of program development studies regarding the teaching of critical thinking skills in each discipline.

The measurement and evaluation dimension are also important for completing the teaching process. In the CoRT course, no application is directly based on the assessment dimension. Furthermore, the teaching and achievement of such skills can be possible at the end of a long training and they are very difficult to measure. In fact, Iwako et al. (2010) stated that it is difficult to measure critical thinking achievements. Tripp (1980) argued that there is a problem regarding what in the program is being investigated and that it is difficult to measure the continuous progress caused by the program.

It is a well-known fact that there are several factors affecting one's learning and working on a subject, and one of them is psychological factors (Seven \& Engin, 2008). Interest and curiosity undoubtedly affect teaching. During this study, students and teachers were 
interested in the lectures and participated willingly. Similarly, Stapleton (2011) stated that teachers expressed their willingness to learn how to teach critical thinking and were in strong support of it in the program. Another reason for the interest of the students may be that the problems were presented as activities and their solutions were requested. This is because problem-solving directly attracts the attention of students and provides active participation (Alagöz, 2011).

We suggest that needs such as including visuals in classes, selecting examples relevant to students' real lives, and having sufficient copies of materials for learners should be fulfilled for practicality purposes. However, it can be stated that these problems are considered normal given the teachers' prejudice against new implementations. According to Gelman and Williams (1998), most teachers and academics expressed doubt about such programs; however, the CoRT program promoted deep thinking, and hence, they supported it. On the other hand, according to the findings, another obstacle for implementation was time constraints in the existing program and oversized classes. Since every obstacle in critical thinking might negatively affect the development of the student's thinking skills (Onosko, 1991), scholars must come together, study the whole program, and work diligently on system integration. Furthermore, the problems might have also been caused by the teachers' shortcomings related to the meaning and teaching of critical thinking. Mandernach (2006) emphasized the importance of combining strategies and activities to develop thinking in the most effective way. Korkmaz (2009) stated that the teachers' critical thinking tendencies and levels were average and that the proportion of teachers with high-level critical thinking tendencies and levels was very low. Similarly, Harold (1938, as cited in Marcut, 2005) stated that teachers should be aware of the development of critical thinking in learners.

\section{References}

Akinoğlu, O. (2001). Eleștirel Düşünme becerilerini temel alan fen bilgisi öğretiminin öğrenme ürünlerine etkisi [The Impact of critical thinking skills-based science education on learning outcomes] (Unpublished PhD Dissertation). Hacettepe University, Institute of Educational Sciences, Ankara.

Alagöz, B. (2011). Probleme dayalı öğrenme yönteminin sosyal bilgiler öğretmen adayları üzerindeki etkisi [The impact of problem-based learning method on social studies teacher candidates]. Millî Eğitim Dergisi, 41(190), 167-187.

Alshurman, W. M. (2017). The effects of the first part of the CoRT program for teaching thinking (BREADTH) on the development of communication skills among a sample of students from $\mathrm{Al}$ alBayt University in Jordan. Educational Research and Reviews, 12(2), 73-82.

Aybek, A. (2007). Konu ve beceri temelli eleştirel düşünme öğretiminin öğretmen adaylarının eleştirel düşünme eğilimi ve düzeyine etkisi [The impact of topic and skill -based teaching of critical thinking on the tendency and level of critical thinking among teacher candidates]. Journal of the Cukurova University Institute of Social Sciences, 16(2), 43-60. 
Barak, M., \& Doppelt, Y. (1999). Integrating the Cognitive Research Trust (CoRT) Programme for Creative Thinking into a Project-based Technology Curriculum. Research in Science \& Technological Education, 17(2), 139-151.

Bayrak, Ç., \& Aktamış, H. (2016). CoRT 1 (Cognitive Research Truth) Düşünme Programının Öğrencilerin Akademik Başarılarına, Bilimsel Yaratıcılıklarına ve Eleştirel Düşünme Eğilimlerine Etkisi:"Yaşamımızdaki Elektrik" Ünitesi Örneği. [The Effects of the CoRT 1 (Cognitive Research Truth) Thinking Program on Students' Academic Achivement, Scientific Creativity and Critical Thinking Tendency: A case of “Electricity In Our Life” Unit]. Uludağ Üniversitesi Eğitim Fakültesi Dergisi, 29(2), 209-230.

Beyer, B. K. (1991) Teaching Thinking Skills: A Handbook for Elementary School Teachers.Boston: Allyn \& Bacon.

Browne, N. M., \& Freeman, K. (2000). Distinguishing features of critical thinking classrooms. Teaching in Higher Education, 5(3), 301-309.

Daher, W., Tabaja-Kidan, A., \& Gierdien, F. (2017). Educating grade-6 students for higher-order thinking and its influence on creativity. Pythagoras, 38(1), 1-12.

De Bono, E. (1986). The CoRT thinking program (2nd ed.). Oxford: Pergamon Press.

De Bono, E. (1991). The direct teaching of thinking in education and the CoRT Method. In S. Maclure \& P. Davies (Eds.), Learning to think: Thinking to learn. Pergamon Press.

Demirkaya, H. (2008). Coğrafya Öğretiminde Eleştirel Düşünme Stratejileri ve Sorgulama Yoluyla Öğrenmenin Kullanımı [Using Critical Thinking Strategies and Inquiry Learning in Geography Instruction]. Türkiye Sosyal Araștırmalar Dergisi, 1, 90-116.

Doğanay, A. (2009). Öğretim ilke ve yöntemleri [Teaching principles and methods], Pegem A. Yayıncılık Indeksi, Ankara.

Doğanay, A. \& Dolapcıoglu, S. (2012). Öğretmen ve öğrenci yansıtma yazılarıyla CORT (Cognitive Research Trust) 5 derslerinin Değerlendirilmesi, 2. Ulusal eğitim programları ve öğretim kongresi. Abstract retrieved from https://www.pegem.net/akademi/kongrebildiri

Elder, L., \& Paul, R. (2002). Critical thinking: Distinguishing between inferences and assumptions. Journal of Developmental Education, 25(3), 34.

Ennis, R. (1991). Critical thinking: A streamlined conception. Teaching philosophy, 14(1), 5-24.

Enright, B. E., \& Beattie, S. A. (1992). Assessing critical thinking in mathematics. Diagnostique, 17(2), 137-144.

Gelman, R., \& Williams, E. (1998). Constraints on cognitive development and learning. In W. Damon (Series Ed.), D. Kuhn, \& R. Siegler (Vol. Eds.), Handbook of child psychology: Vol. 2. Cognition, language, and perception (5th ed., pp. 575-630). New York: Wiley 
Iwaoka, W. T., Li, Y. R., \& Walter, Y. (2010). Measuring gains in critical thinking in food science and human nutrition courses: The Cornell critical thinking test, problem-based learning activities, and student journal entries. Journal of Food Science Education, 9(3), 68-75.

Karakus, M. (2001). Eğitim Programlarında Eleştirel Düşünmeyi Geliştirmenin Bir Yolu Olarak Bilimsel Araştırmalar Vakfı cognitive Research Trust Etkinlikleri [Cognitive Research Trust Activities in Scientific Research Foundation as a Way of Enhancing Critical Thinking in Education Programs]. Cukurova Üniversitesi Sosyal Bilimler Enstitüsü Dergisi, 8(8), 219-237.

Khalid, T. (2010). An integrated inquiry activity in an elementary teaching methods classroom. Science Activities, 47(1), 29-34.

Kirmizi, F. S., \& Akkaya, N. (2010). Yeni türkçe dersi öğretim programının uygulamasına ilişkin olarak branş öğretmenlerinin görüşleri [The views of branch teachers on the implementation of new Turkish language curriculum], Ministry of National Education. 40(185), 33-47.

Korkmaz, Ö. (2009). öğretmenlerin eleştirel düşünme eğilim ve düzeyleri [The tendency and level of critical thinking among teachers), Ahi Evran Üniversitesi Kirşehir Eğitim Fakültesi Dergisi (KEFAD), 10(1), 1-13.

Mandernach, B. J. (2006). Thinking critically about critical thinking: Integrating online tools to promote critical thinking. Insight: A collection of faculty scholarship, 1, 41-50.

Marcut, I. (2005). Critical Thinking: Applied to the Methodology of Teaching Mathematics. Educatia Matematica, 1(1), 57-66.

Merriam, B. (2013). Nitel araştırma desen ve uygulama için bir rehber [Qualitative Research: A Guide to Design and Implementation]. (Translated from the 3rd edition by Turan). Ankara: Nobel Akademik Yayıncllık.

McGregor, D. (2007). Devoloping thinking, devoloping learning. Buckingtam, GBR: Open University Press.

McMillan, J.H. (2004). Educational research: Fundamentals for the consumer. (4th ed.). Boston: Pearson Education, Inc.

Melchior, T. M., Kaufold, R. E., \& Edwards, E. (1988). How schools teach thinking: Using CoRT thinking in schools. Educational Leadership, 45(7), 32-33.

Ngang, T. K., Nair, S., \& Prachak, B. (2014). Developing instruments to measure thinking skills and problem solving skills among Malaysian primary school pupils. Procedia-Social and Behavioral Sciences, 116, 3760-3764.

Onosko, J. J. (1991). Barriers to the promotion of higher-order thinking in social studies. Theory \& Research in Social Education, 19(4), 341-366.

Paul, R., \& Elder, L. (2007). The thinker's guide for students on how to study and learn a discipline using critical thinking concepts and tools. Dillon Beach, CA: Foundation for Critical Thinking. 
Preus, B. (2012). Authentic instruction for 21st century learning: Higher order thinking in an inclusive school. American Secondary Education, 59-79.

Ruppel, R. J. (2011). The intellectual foundations of critical thinking. A Critical Thinking Model at Viterbo University June 15, 2011. Retrieved from the http://www.viterbo.edu/english

Safran, M. et al. (2005), Milli eğitim bakanlığı, ilköğretim sosyal bilgiler dersi 4.-5. sinıflar öğretim programı [Ministry of National Education, Social studies curriculum for 4th and 5th grades in primary school] devlet kitapları müdürlüğü basım evi. [State Book Board Publishing House]

Şenşekerci, E. \& ve Bilgin, A. (2008). Eleştirel Düşünme ve Öğretimi [Critical Thinking and Its Teaching], Uludağ.

Seven, M. A., \& Engin, A. O. (2008). Öğrenmeyi Etkileyen Faktörler [Factors that Influence Learning] Atatürk Üniversitesi Sosyal Bilimler Enstitüsü Dergisi, 12(2), 189-212

Stapleton, P. (2011). A survey of attitudes towards critical thinking among Hong Kong Secondary Teachers: Implications for policy Change. Thinking Skills and Creativity, 6(1), 14-23.

Stoddard, S. (2002). Reflective thinking within an art methods class for preservice elementary teachers. Hawaii international conference on education. Retrieved from www.hiceducation.org.

Tang, C. (2000). Reflective diaries as a means of faciliating and assessing reflection. Hersda 2002 Conference, . Retrieved from www.ecu.edu.au.

Toptaş, V. (2010). İlköğretim matematik dersi (1-5) öğretim programındaki becerilerle ilgili sınıf öğretmenlerinin Görüşleri [The Perceptions of form teachers about the skills in primary school (1-5) mathematics curriculum], Ministry of National Education, 188, 296-310.

Tripp, D. H. (1980). The evulation of the De Bono (CoRT) thinking project; some theoretical issues. Studies in Educational Evaluation, 6(2), 185-194.

White, D. A. (2010). Through Another's Eyes: Gifted Education: Thinking (With Help from Aristotle) about Critical Thinking. Gifted Child Today, 33(3), 14-19.

Yildirim, A., \& Şimşek (2016). H., Sosyal bilimlerde nitel araştırma yöntemleri [Qualitative research methods in social sciences]. Ankara: Seckin.

Yin, R. K. (2009). Case study research (desing and methods). (5.th, ed.). Sage Publication, London. 
Ethics committee approval for this study was obtained from Hatay Mustafa Kemal University Scientific Research and Publication Ethics Committee, dated 23/06/2021 and protocol number 10 .

Statement of Contribution of Researchers to the Article:

1st author contribution rate: $60 \%$

2nd author contribution rate: $40 \%$

Conflict of Interest Statement:

There is no conflict of interest.

Statement of Financial Support or Acknowledgment:

No financial support was received from any institution for this study. 